\title{
Thermal plasticity of growth and chain formation of the dinoflagel- lates Alexandrium affine and Alexandrium pacificum with respect to ocean acidification
}

\author{
Chung Hyeon Lee ${ }^{1,2}$, Juhee Min ${ }^{1,2}$, Hyun-Gwan Lee ${ }^{1,2}$ and Kwang Young Kim ${ }^{1,2, *}$ \\ ${ }^{1}$ Department of Oceanography, College of Natural Sciences, Chonnam National University, Gwangju 61186, Korea \\ ${ }^{2}$ Marine Ecosystem Disturbing and Harmful Organisms (MEDHO) Research Center, Gwangju 61186, Korea
}

The amount of $\mathrm{CO}_{2}$ absorbed by the oceans continues to rise, resulting in further acidification, altering some functional traits of phytoplankton. To understand the effect of elevated partial pressures of $\mathrm{CO}_{2}\left(p \mathrm{CO}_{2}\right)$ on functional traits of dinoflagellates Alexandrium affine and A. pacificum, the cardinal temperatures and chain formation extent were examined under two $p \mathrm{CO}_{2}$ (400 and 1,000 $\mu \mathrm{atm}$ ) over the range of temperature expected to be associated with growth. The growth rate and chain formation extent of A. affine increased with higher $p \mathrm{CO}_{2}$, showing significant changes in cardinal temperatures and a substantial increase in middle chain-length (4-8 cells) fractionation under elevated $p \mathrm{CO}_{2}$ condition. By contrast, there were no significant differences in specific growth rate and any chain-length fractionation of $A$. pacificum between ambient and elevated $p \mathrm{CO}_{2}$ conditions. The observed interspecies variation in the functional traits may reflect differences in ability of species to respond to environmental change with plasticity. Moreover, it allows us to understand the shifting biogeography of marine phytoplankton and predict their phenology in the Korea Strait.

Key Words: Alexandrium affine; Alexandrium pacificum; cardinal temperature; chain formation; growth rate; Korea Strait; ocean acidification

\section{INTRODUCTION}

Because of industrialization, the atmospheric carbon dioxide $\left(\mathrm{CO}_{2}\right)$ concentration increased by about $50 \%$, from $\sim 280 \mathrm{ppm}$ at the beginning of the industrial era to $413 \mathrm{ppm}$ at present (September 2021) (NOAA/GML 2021). This increase in atmospheric $\mathrm{CO}_{2}$ concentration, along with other greenhouse gases, is linearly correlated with the rise of global and oceanic temperatures (NOAA/ NCEI 2021). At the same time, a significant buildup of dissolved $\mathrm{CO}_{2}$ in the upper layer of ocean leads to increased bicarbonate $\left(\mathrm{HCO}_{3}^{-}\right)$concentration, which brings about a decrease in seawater $\mathrm{pH}$ by increasing $\mathrm{H}^{+}$concentration. Consequently, a perturbation of the carbonate buffering system and a process collectively referred to as ocean acidification (OA) occur (Zeebe et al. 2008, Doney et al. 2009). It has been projected that $\mathrm{OA}$ will cause the average $\mathrm{pH}$ of the upper pelagic ocean to drop by $0.3-0.4$ units, which is equivalent to $150 \%$ increase in $\mathrm{H}^{+}$and $50 \%$ decrease in carbonate ion $\left(\mathrm{CO}_{3}{ }^{2-}\right)$ availability (Orr et al. 2005, Gattuso et al. 2015). Also, a drop in the $\mathrm{pH}$ in coastal waters by about 0.45 units is predicted by the end of 2100 (Cai et al. 2011). Although atmospheric inputs are not the only carbon source, this can be used to reliably project the drop in $\mathrm{pH}$ of coastal waters as about $12 \%$ faster than that in epipelagic oceans. The variability of $\mathrm{pH}$, which
(9) $\$$ This is an Open Access article distributed under the terms of the Creative Commons Attribution Non-Commercial License (http://creativecommons.org/licenses/by-nc/3.0/) which permits unrestricted non-commercial use, distribution, and reproduction in any medium, provided the original work is properly cited.
Received October 3, 2021, Accepted December 1, 2021

*Corresponding Author

E-mail: kykim@chonnam.ac.kr

Tel: +82-62-530-3465, Fax: +82-62-530-0065 
is driven by complex physical and biological processes, is often substantially higher in the coastal waters as it is relatively more affected by anthropogenic factors such as eutrophication and organic carbon runoff (Carstensen and Duarte 2019, Ding et al. 2019, He and Silliman 2019).

Notable diurnal or spatial variations in the $\mathrm{pH}$ of coastal waters of the Korea Strait, important for commercial shellfisheries and aquaculture, can range between 6.6 and 8.2 (Kim et al. 2012). However, this range is unrealistic because the lowest $\mathrm{pH}$ value of the Yellow Sea over the past 30 years (1985-2014) was estimated to be 7.6 (Kim et al. 2020). This OA is crucial for marine algae relying on dissolved inorganic carbon (DIC) for photosynthesis and / or calcification and represents a significant threat to marine habitat-forming species, ecosystem function, and associated services (Iglesias-Rodriguez et al. 2008, Hurd et al. 2009, Kroeker et al. 2013, Brondizio et al. 2019, Zunino et al. 2021). The ranges of physiological characteristics of marine organisms can be linked to OA conditions due to altered inorganic carbonate chemistry resulting from increased $\mathrm{HCO}_{3}{ }^{-}$and $\mathrm{H}^{+}$, and decreased $\mathrm{CO}_{3}{ }^{2-}$ and calcium carbonate saturation states (Doney et al. 2009, Kroeker et al. 2013, Riebesell and Gattuso 2015). The higher availability of DIC resulting from OA might be promoting greater photosynthesis and growth of marine phytoplankton that are less efficient in carbon sequestration. For example, many phytoplankton species are positively affected by OA as their productivity, growth rate, and carbon sequestration increasing significantly (Rost et al. 2008, Beardall et al. 2009, Basu and Mackey 2018, Lim et al. 2020). Conversely, reduced $\mathrm{pH}$ and $\mathrm{CO}_{3}{ }^{2-}$ can pose a substantial challenge for marine calcifiers that build their skeletons from calcium carbonate and for species which are sensitive to higher proton levels during photosynthesis (Guinotte and Fabry 2008, Comeau et al. 2013, Kottmeier et al. 2016).

Most marine phytoplanktons, including dinoflagellates, have evolved with sophisticated carbon concentrating mechanisms (CCMs) that help them acquire sufficient $\mathrm{CO}_{2}$ for photosynthesis. $\mathrm{CCM}$ is one of the several types of metabolic processes that facilitate active influx of $\mathrm{CO}_{2}$ and / or bicarbonate ions $\left(\mathrm{HCO}_{3}^{-}\right)$to overcome the limited $\mathrm{CO}_{2}$ availability in the vicinity of RuBisCO (ribulose-1,5-bisphosphate carboxylase / oxygenase) (Raven et al. 2017). Photosynthetic dinoflagellates contain form II RuBisCO that converts carbon dioxide to reduced organic compounds with a poor affinity for $\mathrm{CO}_{2}$ (Reinfelder 2011). However, dinoflagellates are not carbon-limited at the current $\mathrm{CO}_{2}$ levels due to effective CCMs (Fu et al. 2008, van de Waal et al. 2019). They could also benefit from OA by downscaling their CCMs and reallocating energy and resources towards other cellular compartments and biological processes (Rost et al. 2008).

Non-calcifying algae are more likely to benefit from OA, although non-CCM species that depend exclusively on $\mathrm{CO}_{2}$ availability are carbon-limited (Cornwall and Hurd 2016, Ji et al. 2017). For example, OA has been shown to enhance the growth rates of dinoflagellates Amphidinium carterae (Bausch et al. 2019), Alexandrium fundyense (Hattenrath-Lehmann et al. 2015), Alexandrium tamarense (Pang et al. 2017), and Karlodinium veneficum (Fu et al. 2012). Growth rates of bacillariophytes Phaeodactylum tricornutum (Laws et al. 1997) and Thalassiosira pseudonana (Sobrino et al. 2008), raphidophytes Chattonella subsalsa (Fu et al. 2008), and Heterosigma akashiwo (Hennon et al. 2017), and cyanobacteria Prochlorococcus (Bagby and Chisholm 2015) grown in elevated $p \mathrm{CO}_{2}$ environments also increased, while it did not affect the photosynthesis and growth of some species with active CCMs (Cornwall and Hurd 2016). The growth of macroalgae with active CCMs, such as Ulva prolifera and Sargassum muticum, could be enhanced by OA (Gao et al. 2016, Xu et al. 2017). In contrast, adverse effects on growth were observed in dinoflagellates Alexandrium monilatum and Prorocentrum minimum (Hennon et al. 2017) and bacillariophyte Phaeodactylum tricornutum (Laws et al. 1997). For calcifying phytoplankton, such as coccolithophores, it is challenging to overcome enhanced dissolution due to lowered saturation state of calcium carbonate associated with the decrease in carbonate ion $\left(\mathrm{CO}_{3}{ }^{2}\right)$ concentrations caused by OA (Joint et al. 2011, Reusch and Boyd 2013, Hutchins and Fu 2017).

In general, growth rates of phytoplankton increase with warming to a point (optimum temperature) beyond which they decrease sharply. Species from thermally fluctuating environments, like temperate regions, have a broad thermal niche and biogeography, and therefore can tolerate thermal stress or are less sensitive to warming (Pörtner et al. 2017). While many studies have examined the combined effects of OA and warming on phytoplankton ecology (Feng et al. 2009, Kim et al. 2013, Maugendre et al. 2015, Paul et al. 2016, Bénard et al. 2018, Gao et al. 2018), no study has explored the effects of OA on the thermal performance curve (TPC) of growth and chain formation over a wide range of temperatures.

Photosynthetic organisms may acclimate to changed carbonate chemistry within short periods through phenotypic plasticity and genotypic variations for long-term adaptation (Hutchins and Fu 2017, Ding et al. 2019). To project the future trends of proliferation of harmful al- 
gal blooms (HAB) species, it is crucial to understand their physiological and morphological traits, which are highly temperature-dependent (Lee et al. 2019b, Kang et al. 2020, Kruk et al. 2021). Although high temperatures may negatively impact phytoplankton production and biomass, marine species can mitigate some ecological impacts of short-term heatwave and warming events through rapid adaptation and phenotypic plasticity in response to regional environments (Listmann et al. 2016, O'Donnell et al. 2018, Kang et al. 2019b, Lee et al. 2020b). However, these responses of HAB species to OA caused by changing carbonate chemistry still lack experimental evidence.

Alexandrium affine has been reported from arctic to tropical waters (Guiry and Guiry 2021). This ubiquitous species is not considered a paralytic shellfish toxinproducing species, but it produces lytic compounds and other allelochemicals (Basti et al. 2015). In the Korea Strait, A. affine appears throughout the year with an increased abundance during spring to summer, immediately after diatom bloom termination (Lim et al. 2019, Lee et al. 2020a). In contrast, A. pacificum which has the sxtA gene is reported to occur in certain locations in the Pacific region, such as China, Japan, Korea, Australia, and New Zealand (Genovesi et al. 2015, Shin et al. 2017, Dai et al. 2020). In the Korea Strait, A. pacificum appears from late January to early March (Lee et al. 2020a). Thus, differences in biogeography and phenology between two Alexandrium species are anticipated.

Many studies have detailed positive, negative, or neutral impact of OA on the physiology, growth, and morphology of dinoflagellates. However, the effects of OA on Alexandrium species are still uncertain. This study aims to compare the effects of elevated $p \mathrm{CO}_{2}$ on photosynthesis, growth, and chain-forming thermal performances of A. affine and A. pacificum, which have caused notable economic losses in the Korean shellfish industry during the last decades.

\section{MATERIALS AND METHODS}

\section{Species and culturing}

Two species of Alexandrium isolated from the coastal waters of the Korea Strait were used. Alexandrium affine (Aa-MEDHO0710) and A. pacificum (Ap-MEDHO0210) were isolated from Mijo Harbor $\left(34^{\circ} 42^{\prime} \mathrm{N}, 128^{\circ} 03^{\prime} \mathrm{E}\right)$ in September 2007 and Jangmok Bay (34 $59^{\prime} \mathrm{N}, 128^{\circ} 40^{\prime}$ E) in February 2010, respectively. Cultures of these strains were maintained in $\mathrm{f} / 2$ medium without silicate at 20 $23^{\circ} \mathrm{C}$ and $32-34$ psu under a $12: 12 \mathrm{~h}$ light-dark cycle with $\sim 100 \mu \mathrm{mol}$ photons $\mathrm{m}^{-2} \mathrm{~s}^{-1}$, typically containing a mixture of single cells and two- and more than three-cell chains. Alexandrium species-specific primer sets targeting the internal transcribed spacer region (5'-TGTGCTTGACTTTTACATGA-3' and 5'-GAGCAGCACAGATACA-3' for A. affine and 5'-TTCAATGCAAAACATTGACCT-3', and 5'-CTGTTTGCATTTCTCTAGTT-3' for A. pacificum) were applied to verify the identification of species by conventional PCRs (Supplementary Fig. S1).

\section{Experimental setup}

Cells of A. affine and A. pacificum were acclimated in batch mode to the experimental temperatures and $p \mathrm{CO}_{2}$ levels for 14 days before the start of the experiment. Subsequently, A. affine and A. pacificum were cultured semi-continuously with the abundance of 100 cells $\mathrm{mL}^{-1}$ and 200 cells $\mathrm{mL}^{-1}$, respectively. Compared with target $\mathrm{pH}$ values, these relatively low cell densities allowed us to maintain the $\mathrm{pH}$ with minor variations $(<0.10$ units). Cells incubated in 250-mL Erlenmeyer flasks at 33-34 psu under an incident irradiance of $150 \mu \mathrm{mol}$ photons $\mathrm{m}^{-2} \mathrm{~s}^{-1}$ provided by four $36 \mathrm{~W}$ daylight fluorescent lamps (Dulux L 36W/86; Osram, Münich, Germany), with a light-dark cycle of $14: 10 \mathrm{~h}$.

The five target temperatures were controlled using a thermostatically controlled water bath, which allowed control of the temperature within $\pm 0.5^{\circ} \mathrm{C}$ (Supplementary Fig. S2). The temperature was logged every $30 \mathrm{~min}$ using data loggers (Onset Computer Corporation, Pocasset, MA, USA). A given target $p \mathrm{CO}_{2}$ level was manipulated by adding an appropriate amount of $\mathrm{CO}_{2}$-saturated seawater (CSS), no more than $10 \mu \mathrm{L}$. CSS was obtained by bubbling reagent-grade $\mathrm{CO}_{2}$ through seawater in gastight containers with the $\mathrm{pH}$ dropping below 5 . Samples were collected in triplicates from each semi-continuous culture for $\mathrm{pH}_{\mathrm{T}}$ measurements to reset the target $p \mathrm{CO}_{2}$ level. The photosynthetic efficiency and cell counts of the samples were also measured.

All inoculums were transferred weekly to keep them in the exponential growth phase until the start of the experiment. During the semi-continuous cultivation in Erlenmeyer flasks ( $100 \mathrm{~mL}$ capacity), cultures were maintained at the lower section of the exponential phase (Supplementary Fig. S3), and were optically thin to minimize self-shading, $\mathrm{CO}_{2}$ drift, and nutrient limitation. 


\section{Inorganic carbonate chemistry}

The inorganic carbonate chemistry was subsequently calculated with the help of CO2SYS program (Lewis and Wallace 1998) using the total $\mathrm{pH}$ scale $\left(\mathrm{pH}_{\mathrm{T}}\right)$, total alkalinity $\left(A_{\mathrm{T}}\right)$, temperature, and salinity of culture seawater (Lim et al. 2020). The $\mathrm{pH}_{\mathrm{T}}$ on the total hydrogen scale was monitored for each culture every day using a high-resolution UV-VIS spectrophotometer (Agilent 8453; Agilent Technologies, Pal Alto, CA, USA) fitted with $20-\mathrm{mm}$ path length special optical glass spectrophotometric cells (18B-SOG-20, Starna). Absorbances of $30 \mathrm{~mL}$ seawater samples kept at $25^{\circ} \mathrm{C}$ were measured after adding $80 \mu \mathrm{L}$ aliquots of $\mathrm{m}$-cresol purple indicator dye (Sigma-Aldrich Chemical Co., St. Louis, MO, USA) at wavelengths 434, 578 , and $730 \mathrm{~nm}$.

Total alkalinity $\left(A_{\mathrm{T}}\right)$ measurements of each culture were obtained at the beginning and the end of the 10day incubation using potentiometric titration with acid in a semi-closed cell system, consisting of a Metrohm 765 Dosimat titrator (Metrohm, Zofingen, Switzerland) connected to a pH meter (Orion 920A; Thermo Fisher Scientific, Waltham, MA, USA). The electromotive force during titration with acid $(0.13 \mathrm{~N} \mathrm{HCl})$ was recorded using Q-basic software (Millero et al. 1993). $A_{\mathrm{T}}$ values were calibrated against certified seawater reference material (Andrew Dickson, Scripps Institution of Oceanography).

\section{Growth rate and chain formation}

Live cells were enumerated every day in a $1 \mathrm{~mL}$ Sedgewick-Rafter counting chamber on an inverted microscope (IX73; Olympus, Tokyo, Japan). Specific growth rates $(\mu)$ were calculated for each replicate of the applied treatments by fitting an exponential function through all cell counts over time as follows:

$$
N_{\mathrm{t}}=N_{0} \exp ^{\mu t}
$$

, where $N_{\mathrm{t}}$ denotes the cell count at time t, and $N_{0}$ denotes the cell count at the start of each experiment.

Lugol-fixed samples from the harvest day were used for the measurement of chain-forming cells using an inverted microscope (IX73; Olympus). For each replicate, at least 100 single or chain cells were randomly assigned for each treatment.

\section{Cardinal temperature estimation}

The Cardinal Temperature Model with Inflection
(CTMI) in which the maximum specific growth rate $\left(\mu_{\max }\right)$ is described as a function of temperature $\left(\mathrm{T},{ }^{\circ} \mathrm{C}\right)$ alone was used (Rosso et al. 1993). The cardinal temperature parameters were obtained by fitting the CTMI defined as follows:

$$
\begin{gathered}
\mu_{\max }=\mu_{\mathrm{opt}} \frac{\left(T-C T_{\max }\right)\left(T-C T_{\min }\right)^{2}}{\left(T_{\mathrm{opt}}-C T_{\min }\right)} \times \\
\frac{1}{\left[\left(T_{\mathrm{opt}}-C T_{\min }\right)\left(T-T_{\mathrm{opt}}\right)-\left(T_{\mathrm{opt}}-C T_{\max }\right)\left(T_{\mathrm{opt}}+C T_{\min }-2 T\right)\right]}
\end{gathered}
$$

In $C T_{\min } \leq T \leq C T_{\max }$, where $C T_{\min }\left({ }^{\circ} \mathrm{C}\right)$ and $C T_{\max }\left({ }^{\circ} \mathrm{C}\right)$ are the hypothetical lower (minimum) and upper (maximum) critical temperatures, respectively, through which the growth rate is zero. However, we represented $C T_{\min }$ and $C T_{\max }$ as the temperatures at which the growth rate was $5 \%$ of the maximum growth rate due to their ambiguity, that determined the temperature tolerance range $\left(T_{\text {tol }}\right)$. The thermal performance breadth $\left(T B_{80}\right)$ was also defined as the 80th percentile of the CTMI fits where the performance was close to optimal. $T_{\text {opt }}\left({ }^{\circ} \mathrm{C}\right)$ is the temperature at $\mu_{\max }$, and $\mu_{\mathrm{opt}}$ is the specific growth rate at $T_{\mathrm{opt}}$.

\section{Maximum photochemical efficiency of photo- system II}

To determine photosynthetic activity, the maximum efficiency of photosystem II (PSII) photochemistry (i.e., the maximum quantum yield of PSII) was determined using a pulse amplitude-modulated (PAM) chlorophyll- $a$ fluorometry (Phyto-PAM fluorometer; Walz GmbH, Effeltrich, Germany). The maximum quantum yield $\left(F_{\mathrm{v}} / F_{\mathrm{m}}\right)$ for each culture was measured after being acclimatized to darkness for $15 \mathrm{~min}$. Where $F_{\mathrm{v}}$ (variable fluorescence) is calculated as the difference between $F_{\mathrm{o}}$ and $F_{\mathrm{m}}$ fluorescence, where $F_{0}$ is the minimum level of fluorescence in the absence of photosynthetic light at open reaction centers, and $F_{\mathrm{m}}$ is the maximum fluorescence yield induced by a saturation light pulse at closed reaction centers of PSII (Genty et al. 1989).

\section{Statistical analyses}

For experimental measures (carbonate chemistry, maximum efficiency of PSII photochemistry, growth rate, and chain formation), the main and interaction effects of temperature (five levels ranging from 15 to $31^{\circ} \mathrm{C}$ for $A$. affine or $30^{\circ} \mathrm{C}$ for A. pacificum) and $p \mathrm{CO}_{2}$ (ambient and elevated levels) to assess significant responses were evaluated by one- or two-way analyses of variance (ANOVA). 

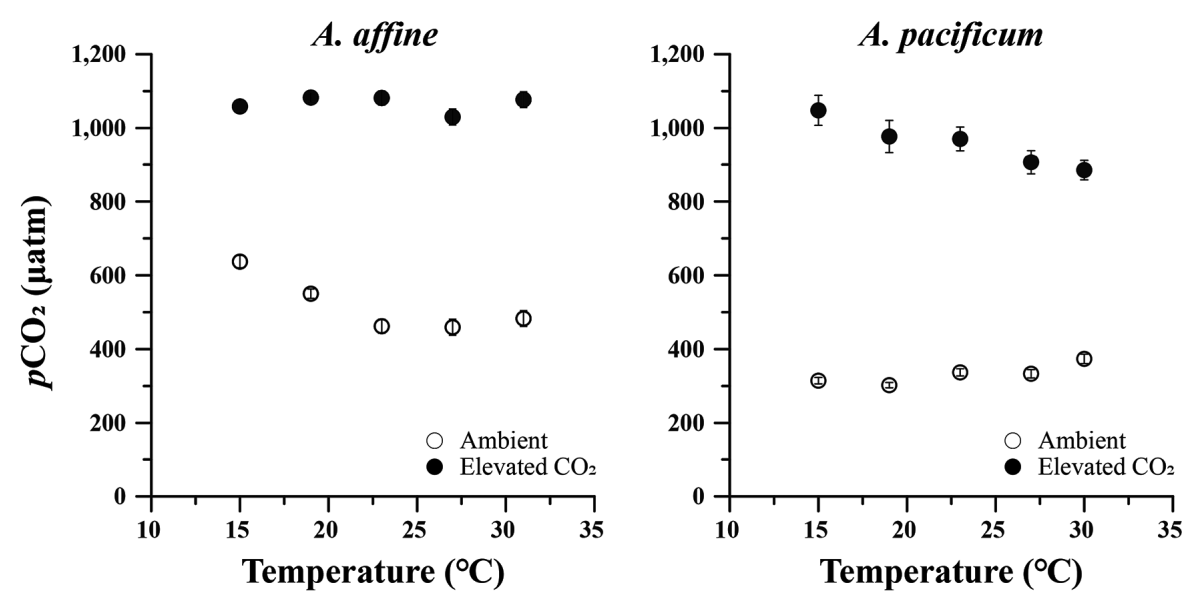

Fig. 1. The different partial pressures of $\mathrm{CO}_{2}\left(p \mathrm{CO}_{2}\right)$ and temperature treatments of Alexandrium affine and A. pacificum cultures, showing the mean \pm standard error $(\mathrm{n}=39)$ in ambient (open circles) and elevated $p \mathrm{CO}_{2}$ (filled circles) conditions over 10 days.
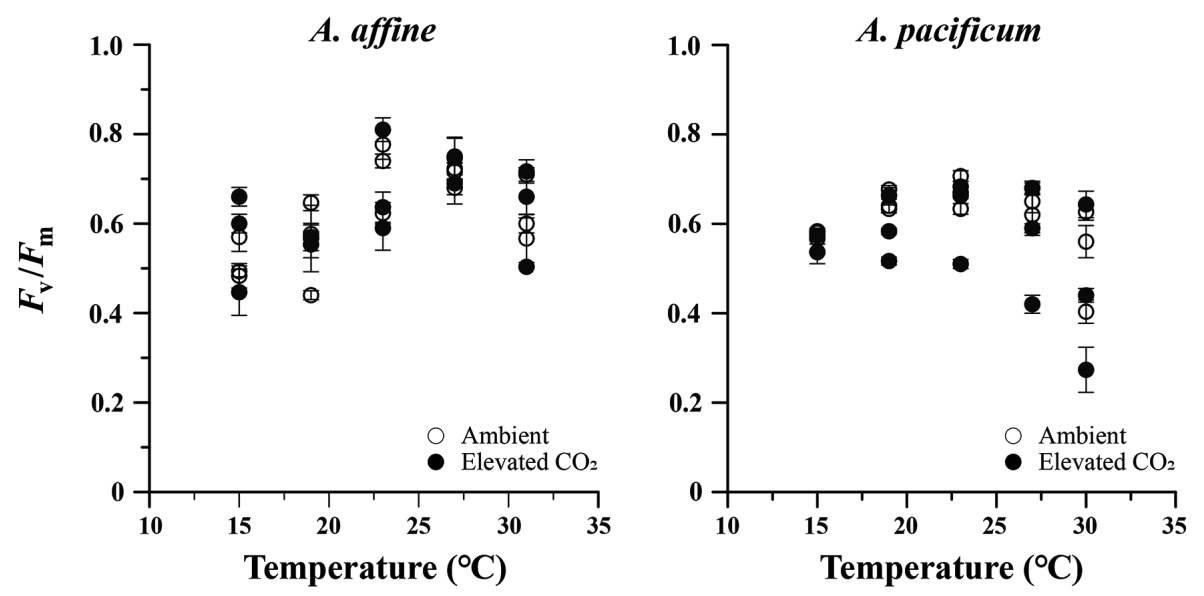

Fig. 2. Maximum photochemical efficiency $\left(F_{\mathrm{v}} / F_{\mathrm{m}}\right)$ of Alexandrium affine and $A$. pacificum in response to partial pressures of $\mathrm{CO}_{2}\left(p \mathrm{CO}_{2}\right)$ and temperature treatments at 4,6 , and 8 days of the experiment. Vertical bars indicate the mean \pm standard error $(n=3)$ for ambient (open circles) and elevated $p \mathrm{CO}_{2}$ (filled circles) conditions.

Data were initially checked for conformity to normality using the Shapiro-Wilk test, and for homogeneity of variances using Levene's test. If a significant ANOVA was found, differences among the group means were evaluated using Turkey's post hoc tests for multiple comparisons. All statistical analyses were performed in SPSS Statistics version 25 (IBM Corp., Armonk, NY, USA).

\section{RESULTS}

The carbonate chemistry levels between the ambient and elevated $p \mathrm{CO}_{2}$ conditions were significantly different for all temperature levels during experiments $(\mathrm{p}<0.05)$ (Tables 1 \& 2, Fig. 1), despite a slight upward drift in $\mathrm{pH}$ during active cell growth. For instance, mean $p \mathrm{CO}_{2}$ ranged from 459 to $637 \mu$ atm in ambient and 1,030 to 1,082 $\mu \mathrm{atm}$ in elevated $p \mathrm{CO}_{2}$ conditions in A. affine cultures (Table 1). In A. pacificum cultures, the mean $p \mathrm{CO}_{2}$ in ambient and elevated $p \mathrm{CO}_{2}$ ranged from 302 to $373 \mu \mathrm{atm}$ and 885 to $1,047 \mu \mathrm{atm}$, respectively (Table 2). The other dissolved carbonate species showed a similar trend.

\section{Comparison between species in the ambient condition}

The values of $F_{\mathrm{v}} / F_{\mathrm{m}}$ (maximum quantum efficiency of PSII) for A. affine gradually increased as temperature increased from 15 to $23^{\circ} \mathrm{C}$ and remained high at 27 and $31^{\circ} \mathrm{C}$. For $A$. pacificum, the $F_{\mathrm{v}} / F_{\mathrm{m}}$ was highest at $23^{\circ} \mathrm{C}$, and showed a clear decreasing trend beyond this temperature (Fig. 2). 
The shape of TPCs and cardinal temperature parameters differed between the species. For instance, the maximum growth rate $\left(\mu_{\max }\right)$ of $A$. affine observed at an optimal temperature $\left(T_{\text {opt }}\right)$ of $26^{\circ} \mathrm{C}$ was $0.54 \mathrm{~d}^{-1}$, which is faster than A. pacificum that had an average growth rate of 0.51 $\mathrm{d}^{-1}$ at a $T_{\text {opt }}$ of $25.3^{\circ} \mathrm{C}$ (Fig. 3). Critical thermal minimum $\left(C T_{\min }\right)$ and critical thermal maximum $\left(C T_{\max }\right)$ were 15.6 and $35.3^{\circ} \mathrm{C}$, respectively, for $A$. affine, and 7.0 and $30.7^{\circ} \mathrm{C}$, respectively, for A. pacificum. Thermal breadth $\left(T B_{80}\right)$ also differed between the species, with the values 8.4 and $7.8^{\circ} \mathrm{C}$ for A. affine and A. pacificum, respectively (Table 3 ).

Percentage of chain-forming cells varied from 28 to $84 \%$ at 15 and $27^{\circ} \mathrm{C}$ for $A$. affine, and from 8 to $57 \%$ at 30 and $23^{\circ} \mathrm{C}$ for $A$. pacificum (Fig. 4). A. pacificum showed a

Table 1. A summary of seawater carbonate chemistry for two target $p \mathrm{CO}_{2}(400$ and $1,000 \mu$ atm $)$ at five temperatures $\left(15,19,23,27\right.$, and $\left.31^{\circ} \mathrm{C}\right)$ treatments of Alexandrium affine, showing the mean \pm standard deviation $(n=39)$ in each treatment over the course of the experiment

\begin{tabular}{|c|c|c|c|c|c|c|}
\hline \multicolumn{2}{|c|}{ Treatment } & \multirow{2}{*}{$\underset{\text { in situ }}{\mathrm{pH}}$} & \multirow{2}{*}{ 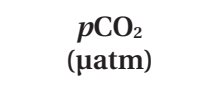 } & \multirow{2}{*}{$\begin{array}{c}\mathrm{HCO}_{3}^{-} \\
\left(\mu \mathrm{mol} \mathrm{kg}{ }^{-1}\right)\end{array}$} & \multirow{2}{*}{$\begin{array}{c}\mathrm{CO}_{3}^{2-} \\
\left(\mu \mathrm{mol} \mathrm{kg}{ }^{-1}\right)\end{array}$} & \multirow{2}{*}{$\begin{array}{c}\mathrm{CO}_{2(\mathrm{aq})} \\
\left(\mu \mathrm{mol} \mathrm{kg}{ }^{-1}\right)\end{array}$} \\
\hline Temperature $\left({ }^{\circ} \mathrm{C}\right)$ & $p \mathrm{CO}_{2}$ ( $\left.\mu \mathrm{atm}\right)$ & & & & & \\
\hline \multirow[t]{2}{*}{15} & 400 & $7.87 \pm 0.08^{\mathrm{a}}$ & $637.0 \pm 189.2^{b}$ & $1,863.5 \pm 73.3^{\mathrm{a}}$ & $152.4 \pm 29.7^{\mathrm{a}}$ & $18.1 \pm 5.4^{\mathrm{b}}$ \\
\hline & 1,000 & $7.66 \pm 0.03^{\mathrm{d}}$ & $1,058.5 \pm 104.3^{\mathrm{c}}$ & $1,967.1 \pm 21.7^{\mathrm{b}}$ & $97.3 \pm 8.8^{\mathrm{d}}$ & $30.1 \pm 3.0^{\mathrm{c}}$ \\
\hline \multirow[t]{2}{*}{19} & 400 & $7.92 \pm 0.05^{\mathrm{b}}$ & $550.1 \pm 92.8^{\mathrm{ab}}$ & $1,864.4 \pm 49.0^{\mathrm{a}}$ & $170.1 \pm 19.9^{\mathrm{b}}$ & $15.6 \pm 2.6^{\mathrm{ab}}$ \\
\hline & 1,000 & $7.66 \pm 0.03^{\mathrm{d}}$ & $1,082.6 \pm 79.4^{\mathrm{c}}$ & $2,022.6 \pm 14.9^{c}$ & $100.1 \pm 6.1^{\mathrm{d}}$ & $30.8 \pm 2.6^{c}$ \\
\hline \multirow[t]{2}{*}{23} & 400 & $7.99 \pm 0.03^{\mathrm{c}}$ & $462.1 \pm 53.2^{\mathrm{a}}$ & $1,841.3 \pm 37.5^{\mathrm{a}}$ & $195.3 \pm 15.3^{\mathrm{c}}$ & $13.1 \pm 1.5^{\mathrm{a}}$ \\
\hline & 1,000 & $7.67 \pm 0.04^{\mathrm{d}}$ & $1,081.5 \pm 118.7^{\mathrm{c}}$ & $2,061.7 \pm 24.4^{\mathrm{bc}}$ & $104.8 \pm 10.0^{\mathrm{d}}$ & $30.8 \pm 3.4^{\mathrm{c}}$ \\
\hline \multirow[t]{2}{*}{27} & 400 & $8.00 \pm 0.04^{\mathrm{c}}$ & $459.3 \pm 57.8^{\mathrm{a}}$ & $1,850.6 \pm 41.3^{\mathrm{a}}$ & $198.9 \pm 16.9^{c}$ & $13.1 \pm 1.6^{\mathrm{a}}$ \\
\hline & 1,000 & $7.68 \pm 0.05^{\mathrm{d}}$ & $1,030.0 \pm 135.0^{\mathrm{c}}$ & $2,023.4 \pm 29.4^{\mathrm{cd}}$ & $106.4 \pm 12.0^{\mathrm{d}}$ & $29.3 \pm 3.8^{\mathrm{c}}$ \\
\hline \multirow[t]{2}{*}{31} & 400 & $7.98 \pm 0.05^{\mathrm{c}}$ & $482.9 \pm 57.9^{\mathrm{a}}$ & $1,870.2 \pm 41.5^{\mathrm{a}}$ & $193.1 \pm 17.0^{\mathrm{c}}$ & $13.7 \pm 1.6^{\mathrm{a}}$ \\
\hline & 1,000 & $7.67 \pm 0.05^{\mathrm{d}}$ & $1,077.0 \pm 133.3^{\mathrm{c}}$ & $2,060.4 \pm 27.9^{\mathrm{d}}$ & $105.4 \pm 11.4^{\mathrm{d}}$ & $30.6 \pm 3.8^{\mathrm{c}}$ \\
\hline
\end{tabular}

Inorganic carbon parameters were calculated using the CO2SYS program (Lewis and Wallace 1998) using total alkalinity $\left(A_{\mathrm{T}}\right)$, total pH scale, salinity, and temperature. Values in the same column having different superscript letters indicate significant difference (Turkey's test after ANOVA, $p<$ 0.05).

Table 2. A summary of seawater carbonate chemistry for two target $p \mathrm{CO}_{2}(400$ and $1,000 \mu$ atm $)$ at five temperatures $\left(15,19,23,27\right.$, and $\left.30^{\circ} \mathrm{C}\right)$ treatments of Alexandrium pacificum, showing the mean \pm standard deviation $(n=39)$ in each treatment over the course of the experiment

\begin{tabular}{|c|c|c|c|c|c|c|}
\hline \multicolumn{2}{|c|}{ Treatment } & \multirow{2}{*}{$\underset{\text { in situ }}{\mathrm{pH}}$} & \multirow{2}{*}{$\begin{array}{c}p \mathrm{CO}_{2} \\
(\mu \mathrm{atm})\end{array}$} & \multirow{2}{*}{$\begin{array}{c}\mathrm{HCO}_{3}^{-} \\
\left(\mu \mathrm{mol} \mathrm{kg}{ }^{-1}\right)\end{array}$} & \multirow{2}{*}{$\begin{array}{c}\mathrm{CO}_{3}^{2-} \\
\left.(\mu \mathrm{mol} \mathrm{kg})^{-1}\right)\end{array}$} & \multirow{2}{*}{$\underset{\left(\mu \mathrm{mol} \mathrm{kg}{ }^{-1}\right.}{\mathrm{CO}_{2(\mathrm{aq})}}$} \\
\hline Temperature $\left({ }^{\circ} \mathrm{C}\right)$ & $p \mathrm{CO}_{2}(\mu \mathrm{atm})$ & & & & & \\
\hline \multirow[t]{2}{*}{15} & 400 & $8.14 \pm 0.03^{\mathrm{a}}$ & $314.5 \pm 54.5^{\mathrm{a}}$ & $1,767.3 \pm 59.0^{\mathrm{a}}$ & $243.1 \pm 24.2^{\mathrm{ab}}$ & $9.4 \pm 1.7^{\mathrm{a}}$ \\
\hline & 1,000 & $7.68 \pm 0.06^{\mathrm{b}}$ & $1,047.9 \pm 253.9^{c}$ & $2,007.5 \pm 45.4^{\mathrm{b}}$ & $98.1 \pm 18.5^{\mathrm{c}}$ & $31.0 \pm 7.4^{\mathrm{c}}$ \\
\hline \multirow[t]{2}{*}{19} & 400 & $8.15 \pm 0.05^{\mathrm{a}}$ & $302.4 \pm 44.6^{\mathrm{a}}$ & $1,745.9 \pm 57.2^{\mathrm{a}}$ & $254.6 \pm 23.4^{\mathrm{b}}$ & $8.8 \pm 1.3^{\mathrm{a}}$ \\
\hline & 1,000 & $7.73 \pm 0.07^{\mathrm{bc}}$ & $977.1 \pm 272.2^{\mathrm{bc}}$ & $2,075.8 \pm 49.7^{\mathrm{c}}$ & $114.6 \pm 20.4^{\mathrm{cd}}$ & $28.7 \pm 7.8^{\mathrm{bc}}$ \\
\hline \multirow[t]{2}{*}{23} & 400 & $8.12 \pm 0.06^{\mathrm{a}}$ & $337.0 \pm 60.0^{\mathrm{a}}$ & $1,771.8 \pm 64.4^{\mathrm{a}}$ & $241.8 \pm 26.4^{\mathrm{ab}}$ & $9.7 \pm 1.7^{\mathrm{a}}$ \\
\hline & 1,000 & $7.73 \pm 0.06^{\mathrm{bc}}$ & $970.4 \pm 201.2^{\mathrm{bc}}$ & $2,068.8 \pm 48.8^{\mathrm{c}}$ & $115.0 \pm 19.8^{\mathrm{cd}}$ & $28.2 \pm 5.7^{\mathrm{bc}}$ \\
\hline \multirow[t]{2}{*}{27} & 400 & $8.12 \pm 0.07^{\mathrm{a}}$ & $333.3 \pm 70.4^{\mathrm{a}}$ & $1,762.8 \pm 77.3^{\mathrm{a}}$ & $247.8 \pm 31.7^{\mathrm{ab}}$ & $9.5 \pm 2.0^{\mathrm{a}}$ \\
\hline & 1,000 & $7.75 \pm 0.09^{\mathrm{bc}}$ & $906.7 \pm 199.4^{\mathrm{bc}}$ & $2,037.5 \pm 55.5^{\mathrm{bc}}$ & $122.2 \pm 22.8^{\mathrm{d}}$ & $26.1 \pm 5.8^{\mathrm{b}}$ \\
\hline \multirow[t]{2}{*}{30} & 400 & $8.08 \pm 0.07^{\mathrm{a}}$ & $373.6 \pm 78.5^{\mathrm{a}}$ & $1,794.8 \pm 72.7^{\mathrm{a}}$ & $228.4 \pm 29.8^{\mathrm{a}}$ & $10.7 \pm 2.2^{\mathrm{a}}$ \\
\hline & 1,000 & $7.76 \pm 0.07^{\mathrm{c}}$ & $885.0 \pm 165.2^{\mathrm{b}}$ & $2,045.4 \pm 52.7^{\mathrm{bc}}$ & $127.8 \pm 21.7^{\mathrm{d}}$ & $25.1 \pm 4.7^{\mathrm{b}}$ \\
\hline
\end{tabular}

Inorganic carbon parameters were calculated using the CO2SYS program (Lewis and Wallace 1998) using total alkalinity $\left(A_{T}\right)$, total pH scale, salinity, and temperature. Values in the same column having different superscript letters indicate significant difference (Turkey's test after ANOVA, $p<$ 0.05).

Table 3. Parameters associated with thermal performance curves for the growth rate of Alexandrium affine and A. pacificum in response to $p \mathrm{CO}_{2}$ (ambient: $400 \mu \mathrm{atm}$, elevated: 1,000 $\mu \mathrm{atm}$ ), as calculated by the Cardinal Temperature Model with Inflection (CTMI) model

\begin{tabular}{ccccccrr}
\hline Treatment & $\boldsymbol{C T}_{\min }$ & $\boldsymbol{C T}_{\max }$ & $\boldsymbol{T}_{\text {opt }}$ & $\boldsymbol{\mu}_{\max }$ & $\boldsymbol{T}_{\text {tol }}$ & $\boldsymbol{T B}_{\mathbf{8 0}}$ & $\mathbf{r}^{2}$ \\
\hline A. affine & & & & & & & \\
$\quad$ Ambient & 15.6 & 35.3 & 26.0 & 0.54 & 19.7 & 8.4 & 0.997 \\
Elevated & 14.9 & 37.1 & 26.0 & 0.60 & 22.2 & 10.2 & 0.997 \\
A. pacificum & & & & & & \\
Ambient & 7.0 & 30.7 & 25.3 & 0.51 & 23.7 & 7.8 & 0.997 \\
Elevated & 9.8 & 30.4 & 24.6 & 0.58 & 20.6 & 7.3 & 0.968 \\
\hline
\end{tabular}

$C T_{\min ,}$ critical thermal minimum (5\%); $C T_{\max ,}$ critical thermal maximum (5\%); $T_{\text {opt, }}$ thermal optimum or optimal temperature; $\mu_{\max ,}$ maximum performance or maximum growth rate; $T_{\text {tol, }}$ thermal tolerance range; $T B_{80}$, thermal performance breadth. 

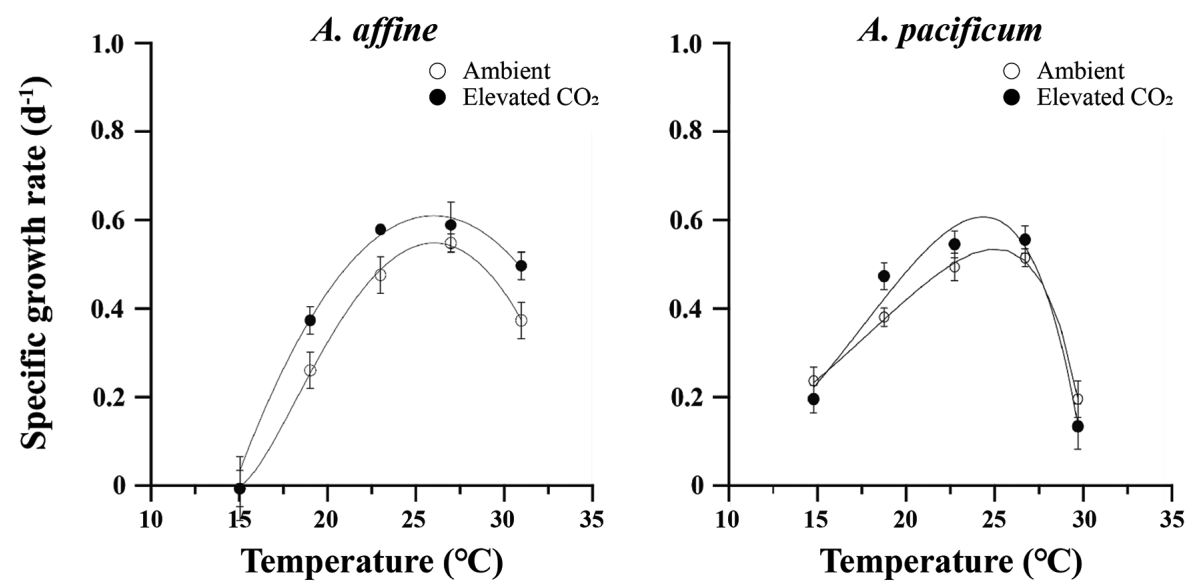

Fig. 3. Specific growth rate $\left(\mu \mathrm{d}^{-1}\right)$ of Alexandrium affine and $A$. pacificum in response to partial pressures of $\mathrm{CO}_{2}\left(p \mathrm{CO}_{2}\right)$ and temperature treatments. Vertical bars indicate the mean \pm standard error $(n=3)$ for ambient (open circles) and elevated $p \mathrm{CO}_{2}$ (filled circles) conditions. Trendlines represent the best fit of the data to the Cardinal Temperature Model with Inflection (CTMI) model of Rosso et al. (1993) with $r^{2}$ of 0.997 (open circles) and 0.997 (filled circles) in A. affine, and 0.997 (open circles) and 0.968 (filled circles) in A. pacificum.
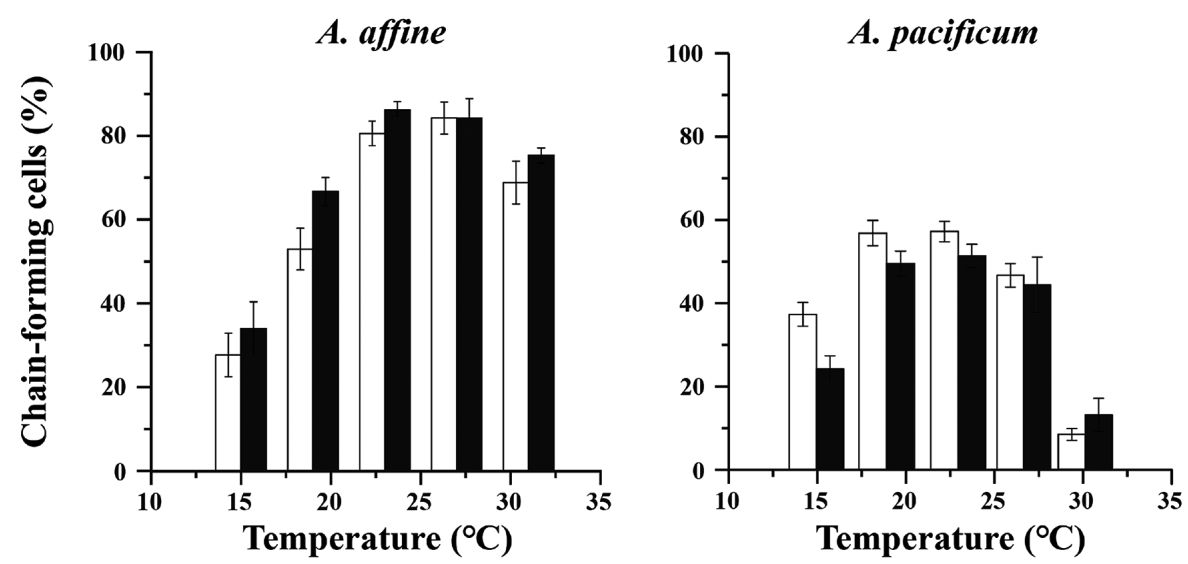

Fig. 4. Percentage of chain-forming cells of Alexandrium affine and A. pacificum in response to partial pressures of $\mathrm{CO}_{2}\left(p \mathrm{CO}_{2}\right)$ and temperature treatments. Vertical bars indicate the mean \pm standard error $(\mathrm{n}=9)$ for ambient (open bar) and elevated $p \mathrm{CO}_{2}$ (filled bar) conditions with different temperature.

lower proportion of cells with chains than A. affine. There were also differences in chain-length fractionation (CF) between the species (Fig. 5). A. affine showed more and various $\mathrm{CF}$ than $A$. pacificum, with a range of $5-40 \%$ of short ( $2-3$ cells), middle ( $4-8$ cells), and long ( $>8$ cells) chains against $2-35 \%$ of primarily short CF across the experimental temperature range.

\section{Comparison between $\mathrm{CO}_{2}$ conditions}

There was no significant interaction between temperature and $p \mathrm{CO}_{2}$ on the $F_{\mathrm{v}} / F_{\mathrm{m}}$ for both species. However, $A$. affine was significantly affected by temperature only ( $\mathrm{p}<0.001$ ), and A. pacificum was significantly af- fected by both temperature and $p \mathrm{CO}_{2}(\mathrm{p}<0.001)$ (Fig. 2, Supplementary Table S1). Exposure to elevated $p \mathrm{CO}_{2}$ lead to only minor increases in the $F_{\mathrm{v}} / F_{\mathrm{m}}$ of $A$. affine within a range of 0.4 to 0.8 , with the most prominent negative effect being observed at the lowest temperature $\left(15^{\circ} \mathrm{C}\right)$ (Fig. 2). Compared to A. affine, the values of $F_{\mathrm{v}} / F_{\mathrm{m}}$ of A. pacificum were somewhat lower at temperatures beyond the optimal temperatures under both ambient and elevated $p \mathrm{CO}_{2}$ conditions.

A. affine showed a significant increase in growth rate as a response to elevated $p \mathrm{CO}_{2}$ compared to ambient conditions $(\mathrm{p}<0.001)$ (Supplementary Table S2). In the same way, its maximum growth rate $\left(\mu_{\max }\right)$ increased by $11 \%$ (from 0.54 to $0.60 \mathrm{~d}^{-1}$ ), $C T_{\max }$ increased from 35.3 to 

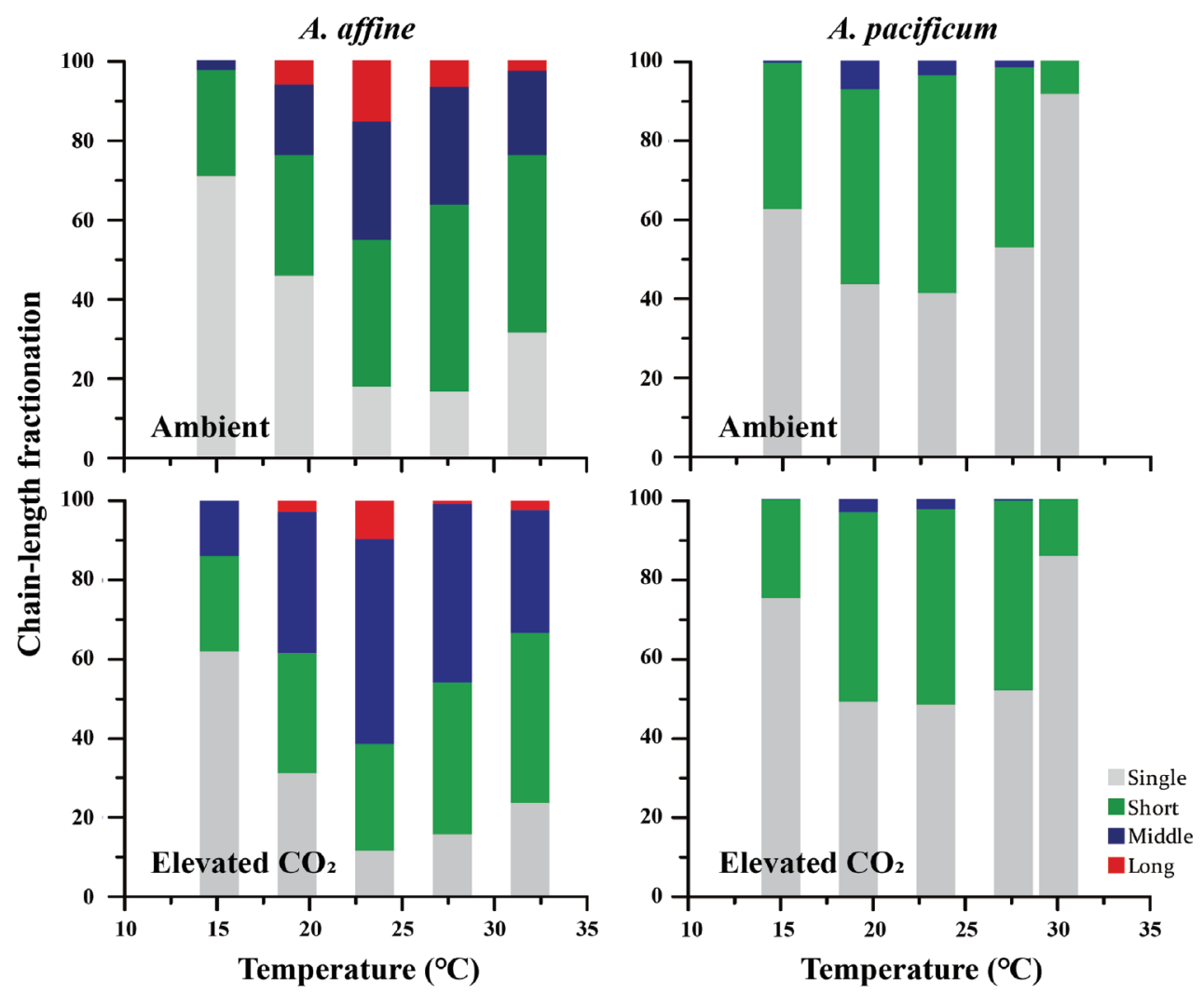

Fig. 5. Chain-length fractionation (CF) of Alexandrium affine and A. pacificum in response to partial pressures of $\mathrm{CO}_{2}\left(p \mathrm{CO}_{2}\right)$ in different temperature treatments. The CF is classified into four categories: single cells (gray), short chain-length (2-3 cells, green), middle chain-length (4-8 cells, blue), and long chain-length ( $>8$ cells, red) $(n=9)$.

$37.1^{\circ} \mathrm{C}$, and $C T_{\min }$ decreased from 15.6 to $14.9^{\circ} \mathrm{C}$, while $T_{\text {opt }}$ remained unchanged at $26.0^{\circ} \mathrm{C}$ for both ambient and elevated $p \mathrm{CO}_{2}$ conditions. Thermal breadth $\left(T B_{80}\right)$ increased from 8.4 to $10.2^{\circ} \mathrm{C}$ only under elevated $p \mathrm{CO}_{2}$ conditions. For A. pacificum there was no significant effect of elevated $p \mathrm{CO}_{2}$ on the growth rate $(\mathrm{p}=0.489)$ (Supplementary Table S2), even its maximum growth rate $\left(\mu_{\max }\right)$ increased from $0.51 \mathrm{~d}^{-1}$ under ambient condition to $0.58 \mathrm{~d}^{-1}$ under elevated $p \mathrm{CO}_{2}$ conditions. $T_{\mathrm{opt}}$ decreased from 25.3 to $24.6^{\circ} \mathrm{C}, C T_{\min }$ increased from 7.0 to $9.8^{\circ} \mathrm{C}$, and $C T_{\max }$ decreased from 30.7 to $30.4^{\circ} \mathrm{C}$ under elevated $p \mathrm{CO}_{2}$ when compared with ambient conditions. Thermal breadth $\left(T B_{80}\right)$ also decreased from 7.8 to $7.3^{\circ} \mathrm{C}$ when such comparison was made. The $T B_{80}$ indicates that $A$. affine was not stressed by the experimental treatments, pointing to its broad temperature tolerance resulting in a wide fundamental niche in respect to the future climate.

The chain-forming capacity did not vary significantly between ambient and elevated $p \mathrm{CO}_{2}$ conditions $(\mathrm{p}>$ 0.01 ), but significant differences between temperatures occurred $(\mathrm{p}<0.001)$ (Supplementary Table S3). The per- centage of chain-forming cells was higher in A. affine than in A. pacificum, that found to markedly increase at their optimal growth temperatures (Fig. 4). A. affine exposed to elevated $p \mathrm{CO}_{2}$ responded by building up chains of various lengths and had higher (but not significantly higher) proportion of chain-forming cells relative to that of ambient $p \mathrm{CO}_{2}$ cultures. In contrast, A. pacificum had only a few cell chains with a slightly higher proportion in ambient than in elevated $p \mathrm{CO}_{2}$ conditions, showing that chain formation was not related to $\mathrm{CO}_{2}$ treatment.

We also tested whether species responded differently to elevated $p \mathrm{CO}_{2}$ for chain-forming trait, and found that only A. affine exhibited a more substantial increase in the proportion of middle chain-length (4-8 cells chain ${ }^{-1}$ ) fractionation, while no change in short chain-length (2-3 cells chain ${ }^{-1}$ ) and long chain-length $\left(>8\right.$ cells chain $\left.{ }^{-1}\right)$ fractionation was found under elevated $p \mathrm{CO}_{2}$ conditions (Fig. 5, Supplementary Table S4). In A. pacificum, elevated $p \mathrm{CO}_{2}$ did not cause a change in CF (Fig. 5, Supplementary Table S5). 


\section{DISCUSSION}

\section{Experimental constraints}

The $\mathrm{pH}$ drift and $\mathrm{CO}_{2}$ exchange in the culture flask were dependent on the growth rate and concentration of cells. In nature, $\mathrm{pH}$ and $p \mathrm{CO}_{2}$ may vary considerably algal blooming, with drastic increases in $\mathrm{pH}$ and reductions in $\mathrm{CO}_{2}$ levels at the bloom peak (Brandenburg et al. 2021). It is unclear whether cells become inhibited by high $\mathrm{pH}$ or limited by low $\mathrm{CO}_{2}$ during the experiment; nevertheless, by allowing $\mathrm{pH}$ drift to occur, the experiment represents changes in carbonate chemistry due to biomass buildup due to some treatments. During the semi-continuous culture, flasks were kept at the lower section of the exponential growth phase (Supplementary Fig. S3) and were maintained at, or below, the starting cell concentration of ca. 100 cells mL $\mathrm{mL}^{-1}$ for $A$. affine and ca. 200 cells $\mathrm{mL}^{-1}$ for $A$. pacificum to avoid self-shading, nutrient limitation, and minimize $\mathrm{CO}_{2}$ exchange. Such experimental cell concentrations are far away from those found in bloom episodes in nature.

\section{Photosynthetic activity}

The maximum quantum yield $\left(F_{\mathrm{v}} / F_{\mathrm{m}}\right)$ has been used as a stress indicator in phototrophic organisms for characterizing the physiological status (Kim et al. 2019). Two Alexandrium tended to increase their $F_{\mathrm{v}} / F_{\mathrm{m}}$ in response to elevated $p \mathrm{CO}_{2}$, but elevated $p \mathrm{CO}_{2}$ had a significant effect only on the $F_{\mathrm{v}} / F_{\mathrm{m}}$ of $A$. pacificum (Supplementary Table S1). The $F_{\mathrm{v}} / F_{\mathrm{m}}$ of $A$. affine showed neither a significant difference between $p \mathrm{CO}_{2}$ conditions nor considerable deterioration across temperature gradients during the experiment. It indicates that $A$. affine is not stressed by the combined treatments, pointing to tolerate broad temperature resulting in a wide fundamental niche in respect to those environmental factors. Various studies support this and generally describe Alexandrium species as eurythermal marine species (Lee et al. 2019a, Lim et al. 2019). Also, an overall increase of the $F_{\mathrm{v}} / F_{\mathrm{m}}$ as considered a marker of its photosynthetic ability reflects its current health status. However, Chl- $a$ fluorescence analysis is not always a reliable method when considering an identifiable $F_{\mathrm{v}} / F_{\mathrm{m}}$ to measure the potential for photosynthetic activity. Note that these measurements represent only a snapshot of bio-optical characteristics of PSII photochemistry that occur within the reaction center complex of PSII (van de Poll et al. 2020).

\section{Thermal performance for growth rate and cardi- nal temperatures}

There was a clear difference between the species in their growth performance response to elevated $p \mathrm{CO}_{2}$ (Fig. 3 ). Overall, the growth rates of $A$. affine showed an apparent increase under elevated $p \mathrm{CO}_{2}$, whereas A. pacificum showed a slight, insignificant increase (Supplementary Table S2). The optimal temperature $\left(T_{\mathrm{opt}}\right)$ of A. pacificum decreased from $25.3^{\circ} \mathrm{C}$ under ambient to $24.6^{\circ} \mathrm{C}$ under elevated $p \mathrm{CO}_{2}$ conditions and was lower than that of $A$. affine (estimated at $26.0^{\circ} \mathrm{C}$ under both conditions) (Table 3). The sharp decline in growth rate above the $T_{\text {opt }}$ of A. pacificum indicates its high sensitivity to heat stress once $T_{\text {opt }}$ is surpassed during summer days in the shallow waters of Korea Strait. In contrast, $A$. affine had a higher critical thermal maximum $\left(C T_{\max }\right)$ compared to A. pacificum, which might indicate a more extraordinary competitive ability of $A$. pacificum to withstand heatwaves prevalent during warm season in the Korea Strait. This could be why the abundance of A. pacificum in the Korea Strait does not increase in summer (Lim et al. 2019, Lee et al. 2020a). Although A. affine is a seasonal species that blooms during the spring-summer months, it is surprising a low abundance of species remains in deep-water of the Korea Strait during the winter months (Lee et al. 2020a), which could have shaped its wide thermal tolerance range $\left(T_{\text {tol }}\right)$ and thermal performance breadth $\left(T B_{80}\right)$.

In this laboratory experiment, thermal breadth $\left(T B_{80}\right)$ of $A$. affine widened by $21 \%$, while that of $A$. pacificum narrowed by $6 \%$ with elevation of $p \mathrm{CO}_{2}$ levels (Table 3 , Fig. 3). Thus, A. affine can be considered as a thermal generalist species, which can tolerate and grow under a wide range of temperatures, with a wide geographical distribution (Farrell 2009). Since both species share habitat and locality in the Korea Strait, the considerable variation in cardinal temperatures may reflect thermal niche partitioning between species, likely arising from enhanced resource use efficiency and interaction in the temperate pelagic system. Two Alexandrium species increased their maximum growth rate $\left(\mu_{\max }\right)$ in response to elevated $p \mathrm{CO}_{2}$ (Table 3). Based on the observed changes in cardinal temperatures, we anticipate the abundance of A. affine to eventually increase in the Korea Strait, given the warming of surface waters and its synergistic effect with increasing $p \mathrm{CO}_{2}$.

Elevating $\mathrm{CO}_{2}$ concentration would favor RuBisCO's carboxylation reaction over oxygenation activity, and further gains in photosynthesis would be granted. The role of CCM is to suppress photorespiration and support 
adequate carbon fixation by enhancing the chemical conditions in the vicinity of the primary $\mathrm{CO}_{2}$ assimilating enzyme RuBisCO (Raven et al. 2017). Although we did not measure CCM activity, dinoflagellates with a high CCM activity also revealed a high CCM plasticity (van de Waal et al. 2019). Therefore, Alexandrium also may possess effective and flexible CCMs. Especially A. affine with high growth rate may have down-regulated their CCMs in the high $\mathrm{CO}_{2}$ condition to reallocate energy towards other cellular processes such as carbon metabolism, cell growth, and chain formation.

\section{Chain formation}

Most phytoplankton species maintain a relatively uniform morphology over time, but others actively change their size by forming chains. Chains form when daughter cells do not separate at the end of cell division, generating highly elongated shapes. Cell size and shape of phytoplankton can be mediated by many essential processes, including light capture, nutrient acquisition, predation, and motility (Pahlow et al. 1997, Smayda 2010, Selander et al. 2011, Bergkvist et al. 2012, Bjærke et al. 2015, Lovecchio et al. 2019). The swimming speed of phytoplankton increases with chain length because chain formation increases propulsion force rather than hydrodynamic drag (Fraga et al. 1989). Chain-forming dinoflagellates, such as Alexandrium species, were observed to swim much faster than single cells (Fraga et al. 1989, Selander et al. 2011, Lovecchio et al. 2019) and to have the ability to migrate vertically between surface waters, during the daytime to harvest light, and deep waters, during the night to consume nutrients (Ryan et al. 2010). Chain length plasticity has been suggested to provide adequate refuge to phytoplankton to reduce encounters with grazers and regulate the balance between motility and grazer avoidance (Selander et al. 2011, Bergkvist et al. 2012, Kang et al. 2019a, Jang and Jeong 2020, You et al. 2020). However, our results from laboratory cultures suggest that maximum capacity of chain formation by Alexandrium species is attained in the absence of grazing pressure, which occurs in the absence of chemical cues released by the grazers. Although the chain formation extent of A. affine and A. pacificum showed varied responses with temperature, no significant effects of $p \mathrm{CO}_{2}$ on the chain formation of both species were observed (Fig. 4, Supplementary Table S3). Moreover, chain length correlates to the growth rate in both species, suggesting that chain length might also depend on growth conditions. In addition, an enhanced response of chain length was observed only in $A$. af- fine, showing that elevated $p \mathrm{CO}_{2}$ significantly enhances the middle CF (4-8 cells chain ${ }^{-1}$ ) (Fig. 5). Differential chain formation responses of A. affine vs. A. pacificum indicate species-specific responses in physiological adjustment and carbon allocation strategies for their growth to cope with OA.

In conclusion, the Alexandrium species are cryptic, sharing similar morphological characteristics, and show phenotypic plasticity within traits in response to elevated $p \mathrm{CO}_{2}$. Two Alexandrium can acclimate their physiology to local environmental conditions within their plastic response range. Although the strains were isolated from the same region, the two species differed strongly in their chain-forming capacity, cardinal temperatures, and response directions under elevated $p \mathrm{CO}_{2}$.

\section{ACKNOWLEDGEMENTS}

We would like to thank Professor MG Park of Chonnam National University for kindly offering Alexandrium strains. This research was supported by a National Research Foundation (NRF) grant funded by the Korean government (MSIT) (NRF-2016R1A6A1A03012647, NRF2020R1A2C3005053) to KYK.

\section{CONFLICTS OF INTEREST}

Kwang Young Kim serves as editor for the Algae, but has no role in the decision to publish this article. All remaining authors have declared no conflicts of interest.

\section{SUPPLEMENTARY MATERIALS}

Supplementary Table S1. Analysis of variance (ANOVA) for the effects of $p \mathrm{CO}_{2}$ (400 and 1,000 $\mu \mathrm{atm}$ ) and temperatures $\left(15,19,23,27\right.$, and 30 or $\left.31^{\circ} \mathrm{C}\right)$ on maximum quantum yield $\left(F_{\mathrm{v}} / F_{\mathrm{m}}\right)$ of Alexandrium affine and A. pacificum (https://www.e-algae.org).

Supplementary Table S2. Analysis of variance (ANOVA) for the effects of $p \mathrm{CO}_{2}$ (400 and 1,000 $\mu \mathrm{atm}$ ) and temperatures $\left(15,19,23,27\right.$, and 30 or $\left.31^{\circ} \mathrm{C}\right)$ on specific growth rate $\left(\mathrm{d}^{-1}\right)$ of Alexandrium affine and A. pacificum (https://www.e-algae.org).

Supplementary Table S3. Analysis of variance (ANOVA) for the effects of $p \mathrm{CO}_{2}$ (400 and 1,000 $\mu \mathrm{atm}$ ) and temperatures $\left(15,19,23,27\right.$, and 30 or $\left.31^{\circ} \mathrm{C}\right)$ on percentage of chain formation in Alexandrium affine and A. pacificum 
(https://www.e-algae.org).

Supplementary Table S4. Two-way analysis of variance (ANOVA) for the effects of $p \mathrm{CO}_{2}$ (400 and 1,000 $\mu \mathrm{atm}$ ) and temperatures $\left(15,19,23,27\right.$, and $\left.31^{\circ} \mathrm{C}\right)$ on chain-length fractionation of Alexandrium affine (https://www.e-algae.org).

Supplementary Table S5. Two-way analysis of variance (ANOVA) for the effects of $p \mathrm{CO}_{2}$ (400 and 1,000 $\mu \mathrm{atm}$ ) and temperatures $\left(15,19,23,27\right.$, and $\left.30^{\circ} \mathrm{C}\right)$ on chain-length fractionation of Alexandrium pacificum (https://www.ealgae.org).

Supplementary Fig. S1. Genotyping Alexandrium affine (left) and A. pacificum (right) with specific primers. Internal transcribed spacer (ITS) targeted amplicons (206 bp for A. affine and $252 \mathrm{bp}$ for A. pacificum) were specifically shown without no PCR product to other species (https://www.e-algae.org).

Supplementary Fig. S2. Temperature of cultures during the thermal performance experiment of Alexandrium affine and $A$. pacificum (green, $15^{\circ} \mathrm{C}$; purple, $19^{\circ} \mathrm{C}$; orange, $23^{\circ} \mathrm{C}$; blue, $27^{\circ} \mathrm{C}$; red, $30^{\circ} \mathrm{C}$ ) (https://www.e-algae.org).

Supplementary Fig. S3. Cell abundance (cells $\mathrm{mL}^{-1}$ ) at various assay temperatures for Alexandrium affine and A. pacificum in ambient (left panels, A \& C) and elevated $p \mathrm{CO}_{2}$ (right panels, $\mathrm{B} \& \mathrm{D}$ ) conditions (green, $15^{\circ} \mathrm{C}$; purple, $19^{\circ} \mathrm{C}$; orange, $23^{\circ} \mathrm{C}$; blue, $27^{\circ} \mathrm{C}$; red, $31^{\circ} \mathrm{C}$ ) (https:// www.e-algae.org).

\section{REFERENCES}

Bagby, S. C. \& Chisholm, S. W. 2015. Response of Prochlorococcus to varying $\mathrm{CO}_{2}: \mathrm{O}_{2}$ ratios. ISME J. 9:2232-2245.

Basti, L., Nagai, S., Go, J., Okano, S., Nagai, K., Watanabe, R., Suzuki, T. \& Tanaka, Y. 2015. Differential inimical effects of Alexandrium spp. and Karenia spp. on cleavage, hatching, and two larval stages of Japanese pearl oyster Pinctada fucata martensii. Harmful Algae 43:1-12.

Basu, S. \& Mackey, K. R. 2018. Phytoplankton as key mediators of the biological carbon pump: their responses to a changing climate. Sustainability 10:869.

Bausch, A. R., Juhl, A. R., Donaher, N. A. \& Cockshutt, A. M. 2019. Combined effects of simulated acidification and hypoxia on the harmful dinoflagellate Amphidinium carterae. Mar. Biol. 166:80.

Beardall, J., Allen, D., Bragg, J., Finkel, Z. V., Flynn, K. J., Quigg, A., Rees, T. A. V., Richardson, A. \& Raven, J. A. 2009. Allometry and stoichiometry of unicellular, colonial and multicellular phytoplankton. New Phytol. 181:295-309.

Bénard, R., Levasseur, M., Scarratt, M., Blais, M. -A., Mucci,
A., Ferreyra, G., Starr, M., Gosselin, M., Tremblay, J. -É. \& Lizotte, M. 2018. Experimental assessment of the sensitivity of an estuarine phytoplankton fall bloom to acidification and warming. Biogeosciences 15:4883-4904.

Bergkvist, J., Thor, P., Jakobsen, H. H., Wängberg, S. -A. \& Selander, E. 2012. Grazer-induced chain length plasticity reduces grazing risk in a marine diatom. Limnol. Oceanogr. 57:318-324.

Bjærke, O., Jonsson, P. R., Alam, A. \& Selander, E. 2015. Is chain length in phytoplankton regulated to evade predation? J. Plankton Res. 37:1110-1119.

Brandenburg, K. M., Krock, B., Klip, H. C. L., Sluijs, A., Garbeva, P. \& Van de Waal, D. B. 2021. Intraspecific variation in multiple trait responses of Alexandrium ostenfeldii towards elevated $p \mathrm{CO}_{2}$. Harmful Algae 101:101970.

Brondizio, E., Diaz, S., Settele, J. \& Ngo, H. T. 2019. IPBES: Global assessment report on biodiversity and ecosystem services of the Intergovernmental Science-Policy Platform on Biodiversity and Ecosystem Services. IPBES Secretariat, Bonn, pp. 680-681.

Cai, W. -J., Hu, X., Huang, W. -J., Murrell, M. C., Lehrter, J. C., Lohrenz, S. E., Chou, W. -C., Zhai, W., Hollibuagh, J. T., Wang, Y., Zhao, P., Guo, X., Gundersen, K., Dai, M. \& Gong, G. -C. 2011. Acidification of subsurface coastal waters enhanced by eutrophication. Nat. Geosci. 4:766-770.

Carstensen, J. \& Duarte, C. M. 2019. Drivers of pH variability in coastal ecosystems. Environ. Sci. Technol. 53:4020-4029.

Comeau, S., Carpenter, R. C. \& Edmunds, P. J. 2013. Coral reef calcifiers buffer their response to ocean acidification using both bicarbonate and carbonate. Proc. R. Soc. B 280:20122374.

Cornwall, C. E. \& Hurd, C. L. 2016. Experimental design in ocean acidification research: problems and solutions. ICES J. Mar. Sci. 73:572-581.

Dai, L., Geng, H. -X., Yu, R. -C., Liu, Y., Zhao, J. -Y., Wang, J. -X., Zhang, Q. -C., Kong, F. -Z. \& Zhou, M. -J. 2020. Distribution of Alexandrium pacificum cysts in the area adjacent to the Changjiang River estuary, China. Mar. Pollut. Bull. 156:111206.

Ding, D., Xing, J., Wang, S., Chang, X. \& Hao, J. 2019. Impacts of emissions and meteorological changes on China's ozone pollution in the warm seasons of 2013 and 2017. Front. Environ. Sci. Eng. 13:76.

Doney, S. C., Balch, W. M., Fabry, V. J. \& Feely, R. A. 2009. Ocean acidification: a critical emerging problem for the ocean sciences. Oceanography 22:16-25.

Farrell, A. P. 2009. Environment, antecedents and climate change: lessons from the study of temperature physi- 
ology and river migration of salmonids. J. Exp. Biol. 212:3771-3780.

Feng, Y., Hare, C. E., Leblanc, K., Rose, J. M., Zhang, Y., DiTullio, G. R., Lee, P. A., Wilhelm, S. W., Rowe, J. M., Sun, J., Nemcek, N., Gueguen, C., Passow, U., Benner, I., Brown, C. \& Hutchins, D. A. 2009. Effects of increased $p \mathrm{CO}_{2}$ and temperature on the North Atlantic spring bloom. I. The phytoplankton community and biogeochemical response. Mar. Ecol. Prog. Ser. 388:13-25.

Fraga, S., Gallager, S. M. \& Anderson, D. M. 1989. Chainforming dinoflagellates: an adaptation to red tides. In Okaichi, T., Anderson, D. M. \& Nemoto, T. (Eds.) Red Tides: Biology, Environmental Science, and Toxicology. Elsevie, Amsterdam, pp. 281-284.

Fu, F. X., Tatters, A. O. \& Hutchins, D. A. 2012. Global change and the future of harmful algal blooms in the ocean. Mar. Ecol. Prog. Ser. 470:207-233.

Fu, F. -X., Zhang, Y., Warner, M. E., Feng, Y., Sun, J. \& Hutchins, D. A. 2008. A comparison of future increased $\mathrm{CO}_{2}$ and temperature effects on sympatric Heterosigma akashiwo and Prorocentrum minimum. Harmful Algae 7:76-90.

Gao, G., Liu, Y., Li, X., Feng, Z. \& Xu, J. 2016. An ocean acidification acclimatised green tide alga is robust to changes of seawater carbon chemistry but vulnerable to light stress. PLoS ONE 11:e0169040.

Gao, K., Zhang, Y. \& Häder, D. -P. 2018. Individual and interactive effects of ocean acidification, global warming, and UV radiation on phytoplankton. J. Appl. Phycol. 30:743-759.

Gattuso, J. -P., Magnan, A., Billé, R., Cheung, W. W. L., Howes, E. L., Joos, F., Allemand, D., Bopp, L., Cooley, S. R., Eakin, C. M., Hoegh-Guldberg, O., Kelly, R. P., Pörtner, H. -O., Rogers, A. D., Baxer, J. M., Laffoley, D., Osborna, D., Rankovic, A., Rochette, J., Sumaila, U. R., Treyer, S. \& Turley, C. 2015. Contrasting futures for ocean and society from different anthropogenic $\mathrm{CO}_{2}$ emissions scenarios. Science 349:aac4722.

Genovesi, B., Berrebi, P., Nagai, S., Reynaud, N., Wang, J. \& Masseret, E. 2015. Geographic structure evidenced in the toxic dinoflagellate Alexandrium pacificum Litaker (A. catenella-group IV (Whedon \& Kofoid) Balech) along Japanese and Chinese coastal waters. Mar. Pollut. Bull. 98:95-105.

Genty, B., Briantais, J. -M. \& Baker, N. R. 1989. The relationship between the quantum yield of photosynthesis electron transport and quenching of chlorophyll fluorescence. Biochim. Biophys. Acta Gen. Subj. 990:87-92.

Guinotte, J. M. \& Fabry, V. J. 2008. Ocean acidification and its potential effects on marine ecosystems. Ann. N. Y. Acad.
Sci. 1134:320-342.

Guiry, M. D. \& Guiry, G. M. 2021. AlgaeBase. World-wide electronic publication, National University of Ireland, Galway. Available from: https://www.algaebase.org. Accessed Jan 14, 2021.

Hattenrath-Lehmann, T. K., Smith, J. L., Wallace, R. B., Merlo, L., Koch, F., Mittelsdorf, H., Goleski, J. A., Anderson, D. M. \& Gobler, C. J. 2015. The effects of elevated $\mathrm{CO}_{2}$ on the growth and toxicity of field populations and cultures of the saxitoxin-producing dinoflagellate, Alexandrium fundyense. Limnol. Oceanogr. 60:198-214.

He, Q. \& Silliman, B. R. 2019. Climate change, human impacts, and coastal ecosystems in the Anthropocene. Curr. Biol. 29:R1021-R1035.

Hennon, G. M. M., Hernández Limón, M. D., Haley, S. T., Juhl, A. R. \& Dyhrman, S. T. 2017. Diverse $\mathrm{CO}_{2}$-induced responses in physiology and gene expression among eukaryotic phytoplankton. Front. Microbiol. 8:2547.

Hurd, C. L., Hepburn, C. D., Currie, K. I., Raven, J. A. \& Hunter, K. A. 2009. Testing the effects of ocean acidification on algal metabolism: considerations for experimental designs. J. Phycol. 45:1236-1251.

Hutchins, D. A. \& Fu, F. 2017. Microorganisms and ocean global change. Nat. Microbiol. 2:17058.

Iglesias-Rodriguez, M. D., Halloran, P. R., Rickaby, R. E. M., Hall, I. R., Colmenero-Hidalgo, E., Gittins, J. R., Green, D. R. H., Tyrrell, T., Gibbs, S. J., von Dassow, P., Rehm, E., Armbrust, E. V. \& Boessenkool, K. P. 2008. Phytoplankton calcification in a high- $\mathrm{CO}_{2}$ world. Science 320:336-340.

Jang, S. H. \& Jeong, H. J. 2020. Spatio-temporal distributions of the newly described mixotrophic dinoflagellate Yihiella yeosuensis (Suessiaceae) in Korean coastal waters and its grazing impact on prey populations. Algae 35:45-59.

Ji, X., Verspagen, J. M. H., Stomp, M. \& Huisman, J. 2017. Competition between cyanobacteria and green algae at low versus elevated $\mathrm{CO}_{2}$ : who will win, and why? J. Exp. Bot. 68:3815-3828.

Joint, I., Doney, S. C. \& Karl, D. M. 2011. Will ocean acidification affect marine microbes? ISME J. 5:1-7.

Kang, H. C., Jeong, H. J., Jang, S. H. \& Lee, K. H. 2019a. Feeding by common heterotrophic protists on the phototrophic dinoflagellate Biecheleriopsis adriatica (Suessiaceae) compared to that of other suessioid dinoflagellates. Algae 34:127-140.

Kang, H. C., Jeong, H. J., Lim, A. S., Ok, J. H., You, J. H., Park, S. A., Lee, S. Y. \& Eom, S. H. 2020. Effects of temperature on the growth and ingestion rates of the newly described mixotrophic dinoflagellate Yihiella yeosuensis and its two optimal prey species. Algae 35:263-275. 
Kang, H. C., Jeong, H. J., Ok, J. H., You, J. H., Jang, S. H., Lee, S. Y., Lee, K. H., Park, J. Y. \& Rho, J. -R. 2019b. Spatial and seasonal distributions of the phototrophic dinoflagellate Biecheleriopsis adriatica (Suessiaceae) in Korea: quantification using qPCR. Algae 34:111-126.

Kim, H. M., Jo, J., Park, C., Choi, B. -J., Lee, H. -G. \& Kim, K. Y. 2019. Epibionts associated with floating Sargassum horneri in the Korea Strait. Algae 34:303-313.

Kim, J. -H., Kim, K. Y., Kang, E. J., Lee, K., Kim, J. -M., Park, K. -T., Shin, K., Hyun, B. \& Jeong, H. J. 2013. Enhancement of photosynthetic carbon assimilation efficiency by phytoplankton in the future coastal ocean. Biogeosciences 10:7525-7535.

Kim, J. -M., Lee, K., Han, I. -S., Lee, J. -S., Choi, Y. -H., Lee, J. H. \& Moon, J. -Y. 2020. Anthropogenic nitrogen-induced changes in seasonal carbonate dynamics in a productive coastal environment. Geophys. Res. Lett. 47:e2020GL088232.

Kim, S. -Y., Lee, Y. -H., Kim, Y. -S., Shim, J. -H., Ye, M. -J., Jeon, J. -W., Hwang, J. -R. \& Jeon, S. -H. 2012. Characteristics of marine environmental in the hypoxic season at Jinhae Bay in 2010. Korean J. Nat. Conserv. 6:115-129.

Kottmeier, D. M., Rokitta, S. D. \& Rost, B. 2016. $\mathrm{H}^{+}$-driven increase in $\mathrm{CO}_{2}$ uptake and decrease in $\mathrm{HCO}_{3}^{-}$uptake explain coccolithophores' acclimation responses to ocean acidification. Limnol. Oceanogr. 61:2045-2057.

Kroeker, K. J., Kordas, R. L., Crim, R., Hendriks, I. E., Ramajo, L., Singh, G. S., Duarte, C. M. \& Gattuso, J. -P. 2013. Impacts of ocean acidification on marine organisms: quantifying sensitivities and interaction with warming. Glob. Change Biol. 19:1884-1896.

Kruk, C., Piccini, C., Devercelli, M., Nogueira, L., Accattatis, V., Sampognaro, L. \& Segura, A. M. 2021. A trait-based approach predicting community assembly and dominance of microbial invasive species. Oikos 130:571-586.

Laws, E. A., Bidigare, R. R. \& Popp, B. N. 1997. Effect of growth rate and $\mathrm{CO}_{2}$ concentration on carbon isotopic fractionation by the marine diatom Phaeodactylum tricornutum. Limnol. Oceanogr. 42:1552-1560.

Lee, H. -G., Kim, H. M., Min, J., Park, C., Jeong, H. J., Lee, K. \& Kim, K. Y. 2020a. Quantification of the paralytic shellfish poisoning dinoflagellate Alexandrium species using a digital PCR. Harmful Algae 92:101726.

Lee, K. H., Jeong, H. J., Kang, H. C., Ok, J. H., You, J. H. \& Park, S. A. 2019a. Growth rates and nitrate uptake of cooccurring red-tide dinoflagellates Alexandrium affine and $A$. fraterculus as a function of nitrate concentration under light-dark and continuous light conditions. Algae 34:237-251.

Lee, S. Y., Jeong, H. J., Kwon, J. E., You, J. H., Kim, S. J., Ok,
J. H., Kang, H. C. \& Park, J. Y. 2019b. First report of the photosynthetic dinoflagellate Heterocapsa minima in the Pacific Ocean: morphological and genetic characterizations and the nationwide distribution in Korea. Algae 34:7-21.

Lee, S. Y., Jeong, H. J., Ok, J. H., Kang, H. C. \&You, J. H., $2020 b$. Spatial-temporal distributions of the newly described mixotrophic dinoflagellate Gymnodinium smaydae in Korean coastal waters. Algae 35:225-236.

Lewis, E. R. \& Wallace, D. W. R. 1998. Program developed for $\mathrm{CO}_{2}$ system calculations. Carbon Dioxide Information Center. Oak Ridge National Laboratory, U.S. Department of Energy, Oak Ridge, 38 pp.

Lim, A. S., Jeong, H. J. \& Ok, J. H. 2019. Five Alexandrium species lacking mixotrophic ability. Algae 34:289-301.

Lim, M. H., Lee, C. H., Min, J., Lee, H. -G. \& Kim, K. Y. 2020. Effect of elevated $p \mathrm{CO}_{2}$ on thermal performance of Chattonella marina and Chattonella ovata (Raphidophyceae). Algae 35:375-388.

Listmann, L., LeRoch, M., Schlüter, L., Thomas, M. K. \& Reusch, T. B. H. 2016. Swift thermal reaction norm evolution in a key marine phytoplankton species. Evol. Appl. 9:1156-1164.

Lovecchio, S., Climent, E., Stocker, R. \& Durham, W. M. 2019. Chain formation can enhance the vertical migration of phytoplankton through turbulence. Sci. Adv. 5:eaaw7879.

Maugendre, L., Gattuso, J. -P., Louis, J., De Kluijver, A., Marro, S., Soetaert, K. \& Gazeau, F. 2015. Effect of ocean warming and acidification on a plankton community in the NW Mediterranean Sea. ICES J. Mar. Sci. 72:1744-1755.

Millero, F. J., Zhang, J. -Z., Lee, K. \& Campbell, D. M. 1993. Titration alkalinity of seawater. Mar. Chem. 44:153-165.

NOAA/GML (ESRL's Global Monitoring Laboratory of the National Oceanic and Atmospheric Administration). 2021. Trends in atmospheric carbon dioxide. Available from: https://gml.noaa.gov/ccgg/trends/. Accessed Sep 30, 2021.

NOAA/NCEI (National Centers for Environmental Information of the National Oceanic and Atmospheric Administration). 2021. Global climate report. Available from: https://www.ncdc.noaa.gov/sotc/global/. Accessed Sep 30, 2021.

O’Donnell, D. R., Hamman, C. R., Johnson, E. C., Kremer, C. T., Klausmeier, C. A. \& Litchman, E. 2018. Rapid thermal adaptation in a marine diatom reveals constraints and trade-offs. Glob. Change Biol. 24:4554-4565.

Orr, J. C., Fabry, V. J., Aumont, O., Bopp, L., Doney, S. C., Feely, R. A., Gnanadesikan, A., Gruber, N., Ishida, A., Joos, F, Key, R. M., Lindsay, K., Maier-Reimer, E., Matear, R., 
Monfray, P., Mouchet, A., Najjar, R. G., Plattner, G. -K., Rodgers, K. B., Sabine, C. L., Sarmiento, J. L., Schlitzer, R., Slater, R. D., Totterdell, I. J., Weirig, M. -F., Yamanaka, Y. \& Yool, A. 2005. Anthropogenic ocean acidification over the twenty-first century and its impact on calcifying organisms. Nature 437:681-686.

Pahlow, M., Riebesell, U. \& Wolf-Gladrow, D. A. 1997. Impact of cell shape and chain formation on nutrient acquisition by marine diatoms. Limnol. Oceanogr. 42:1660-1672.

Pang, M., Xu, J., Qu, P., Mao, X., Wu, Z., Xin, M., Sun, P., Wang, Z., Zhang, X. \& Chen, H. 2017. Effect of $\mathrm{CO}_{2}$ on growth and toxicity of Alexandrium tamarense from the East China Sea, a major producer of paralytic shellfish toxins. Harmful Algae 68:240-247.

Paul, C., Sommer, U., Garzke, J., Moustaka-Gouni, M., Paul, A. \& Matthiessen, B. 2016. Effects of increased $\mathrm{CO}_{2}$ concentration on nutrient limited coastal summer plankton depend on temperature. Limnol. Oceanogr. 61:853-868.

Pörtner, H. -O., Bock, C. \& Mark, F. C. 2017. Oxygen- and capacity-limited thermal tolerance: bridging ecology and physiology. J. Exp. Biol. 220:2685-2696.

Raven, J. A., Beardall, J. \& Sánchez-Baracaldo, P. 2017. The possible evolution and future of $\mathrm{CO}_{2}$-concentrating mechanisms. J. Exp. Bot. 68:3701-3716.

Reinfelder, J. R. 2011. Carbon concentrating mechanisms in eukaryotic marine phytoplankton. Ann. Rrev. Mar. Sci. 3:291-315.

Reusch, T. B. H. \& Boyd, P. W. 2013. Experimental evolution meets marine phytoplankton. Evolution 67:1849-1859.

Riebesell, U. \& Gattuso, J. -P. 2015. Lessons learned from ocean acidification research. Nat. Clim. Chang. 5:12-14.

Rosso, L., Lobry, J. R. \& Flandrois, J. P. 1993. An unexpected correlation between cardinal temperatures of microbial growth highlighted by a new model. J. Theor. Biol. 162:447-463.

Rost, B., Zondervan, I. \& Wolf-Gladrow, D. 2008. Sensitivity of phytoplankton to future changes in ocean carbonate chemistry: current knowledge, contradictions and research directions. Mar. Ecol. Prog. Ser. 373:227-237.

Ryan, J. P., McManus, M. A. \& Sullivan, J. M. 2010. Interacting physical, chemical and biological forcing of phytoplankton thin-layer variability in Monterey Bay, Califor- nia. Cont. Shelf Res. 30:7-16.

Selander, E., Jakobsen, H. H., Lombard, F. \& Kiørboe, T. 2011. Grazer cues induce stealth behavior in marine dinoflagellates. Proc. Natl. Acad. Sci. U. S. A. 108:4030-4034.

Shin, H. H., Li, Z., Kim, E. S., Park, J. -W. \& Lim, W. A. 2017. Which species, Alexandrium catenella (Group I) or A. pacificum (Group IV), is really responsible for past paralytic shellfish poisoning outbreaks in Jinhae-Masan Bay, Korea? Harmful Algae 68:31-39.

Smayda, T. J. 2010. Adaptations and selection of harmful and other dinoflagellate species in upwelling systems. 2. Motility and migratory behaviour. Prog. Oceanogr. 85:71-91.

Sobrino, C., Ward, M. L. \& Neale, P. J. 2008. Acclimation to elevated carbon dioxide and ultraviolet radiation in the diatom Thalassiosira pseudonana: effects on growth, photosynthesis, and spectral sensitivity of photoinhibition. Limnol. Oceanogr. 53:494-505.

van de Poll, W. H., Abdullah, E., Visser, R. J. W., Fischer, P. \& Buma, A. G. J. 2020. Taxon-specific dark survival of diatoms and flagellates affects Arctic phytoplankton composition during the polar night and early spring. Limnol. Oceanogr. 65:903-914.

van de Waal, D. B., Brandenburg, K. M., Keuskamp, J., Trimborn, S., Rokitta, S., Kranz, S. A. \& Rost, B. 2019. Highest plasticity of carbon-concentrating mechanisms in earliest evolved phytoplankton. Limnol. Oceanogr. Lett. 4:37-43.

Xu, Z., Gao, G., Xu, J. \& Wu, H. 2017. Physiological response of a golden tide alga (Sargassum muticum) to the interaction of ocean acidification and phosphorus enrichment. Biogeosciences 14:671-681.

You, J. H., Jeong, H. J., Kang, H. C., Ok, J. H., Park, S. A. \& Lim, A. S. 2020. Feeding by common heterotrophic protist predators on seven Prorocentrum species. Algae 35:61-78.

Zeebe, R. E., Zachos, J. C., Caldeira, K. \& Tyrrell, T. 2008. Carbon emissions and acidification. Science 321:51-52.

Zunino, S., Libralato, S., Canu, D. M., Prato, G. \& Solidoro, C. 2021. Impact of ocean acidification on ecosystem functioning and services in habitat-forming species and marine ecosystems. Ecosystems 24:1561-1575. 